\title{
Impact of Sugarcane Bagasse Ash as an Amendment on the Physical Properties, Nutrient Content and Seedling Growth of a Certified Organic Greenhouse Growing Media
}

\author{
Charles L. Webber III ${ }^{1}$, Paul M. White Jr. ${ }^{1}$, Douglas J. Spaunhorst ${ }^{1} \&$ Eric C. Petrie ${ }^{1}$ \\ ${ }^{1}$ USDA, Agriculture Research Service, Sugarcane Research Unit, Houma, LA, USA \\ Correspondence: Charles L. Webber III, Research Agronomist, USDA, Agriculture Research Service, Sugarcane \\ Research Unit, Houma, LA 70360, USA. E-mail: chuck.webber@ars.usda.gov
}

Received: April 6, 2017

Accepted: May 4, 2017 Online Published: June 15, 2017

doi:10.5539/jas.v9n7p1

\author{
URL: https://doi.org/10.5539/jas.v9n7p1
}

\begin{abstract}
Sugarcane bagasse is the fibrous material remaining after removing the sucrose, water, and other impurities (filter mud) from the millable sugarcane. Louisiana sugarcane mills use a portion of the sugarcane bagasse to produce steam power to run equipment within the mill and/or as a boiler fuel for the clarification, evaporation, and crystallization processes. Sugarcane bagasse ash (SBA) is a by-product of the thermal conversion of the sugarcane bagasse. The purpose of this research was to investigate the use of SBA as an amendment to soilless planting media for the production of vegetable seedlings. The SBA was combined by volume with a commercial certified organic soilless growing media into 5 combinations $(0 \%: 100 \%, 25 \%: 75 \%, 50 \%: 50 \%, 75 \%: 25 \%$, and 100\%:0\%, SBA and growing media, respectively). Bean (Phaseolus vulgaris L.) var. 'Bowie' and Chinese kale (Brassica alboglabra) var. 'South Sea' were planted in each of the 5 different planting mixtures. As the percentage of SBA increased from $0 \%$ to $100 \%$, the bulk densities increased, 0.118 to $0.712 \mathrm{~g} / \mathrm{cm}^{3}$, while the porosity, water saturation percentage, and water at field capacity decreased. Increasing the SBA percentage significantly impacted total exchange capacity, $\mathrm{pH}$, organic matter, estimated nitrogen release, and all other nutrients measured, except for sodium. The research indicates that the addition of SBA can enhance bean and Chinese kale seedling growth depending on the percentage of the ash added to the growth media. Bean and Chinese kale harvest parameters typically peaked at 25\% SBA, and then decreased with increasing SBA \%. Adding $25 \%$ SBA did benefit the seedling growth by providing additional nutrients for seedling growth, while reducing the cost of production by supplementing the more expensive greenhouse media by a readily available by-product of the sugarcane industry. Increasing the SBA \% to $50 \%$ or greater is not recommend. Additional research is needed to determine the percentage above $25 \%$ and below $50 \%$ SBA that would still benefit seedling plant growth.
\end{abstract}

Keywords: agricultural by-products, bagasse, certified organic, fly ash, soilless growth media, sugarcane

\section{Introduction}

\subsection{Sugarcane Bagasse Uses}

In 2014, Louisiana sugarcane farmers harvested 11.6 million mt millable sugarcane from 154,000 ha, producing 1.36 million mg of raw sugar and an estimated 3.5 million mt of bagasse (American Sugar Cane League, 2015). Global sugar production in 2015 was over 170 million mt of raw sugar, which resulted in over 300 million $\mathrm{Mg}$ of bagasse (United States Department of Agriculture, 2015). Bagasse is the fibrous material remaining after removing the sucrose, water, and other extraneous material impurities (e.g. sediment) from the delivered sugarcane. Bagasse on a dry weight basis is composed of $40-50 \%$ cellulose, $30-35 \%$ hemicellulose, $20-30 \%$ lignin, and a small percentage of other materials (Amin, 2011; Cardona et al., 2010; Drummond \& Drummond, 1996; Martin et al., 2007; Pandey et al., 2000; Sales \& Lima, 2010). Sugarcane bagasse has been used for paper and fiber board production (Amin, 2011; Xin et al., 2002), cattle feed (Nigam, 1990; Pandey et al., 2000), potting media (Jhurree-Dussoruth \& Kallydin, 2011; Trochoulias et al., 1990), a source for value added products (i.e. pigments, enzymes, amino acids, and drugs) (Pandey et al., 2000), and energy production (thermal conversion and ethanol) (Badger, 2002; Kilicaslan et al., 1999; Martin et al., 2007; Peng et al., 2009; Sun \& Cheng, 2002). 


\subsection{Sugarcane Bagasse Ash Production}

It is very common for Louisiana sugarcane mills to burn a portion of the sugarcane bagasse to produce steam power to run equipment within the mill and/or as a boiler fuel for the clarification, evaporation, and crystallization processes. Sugarcane bagasse ash (SBA) is a by-product of the thermal conversion of the sugarcane bagasse. Depending on the source of the sugarcane, harvesting methods and thermal conversion efficiency at the mill, the percentage of ash produced from bagasse typically represents a small percentage, 1.5 to $3.0 \%$ by weight, of the original sugarcane bagasse (Amin, 2011; Garcia-Pèrez, 2002). And, although SBA content is low (1.5-3.0\%) compared to other agricultural sources such as rice straw, $14.5 \%$ (Guo et al., 2009) and wheat straw, $8.6 \%$ (Biricik et al., 1999), the large volume of bagasse used for fuel results in massive amounts of SBA that necessitates economically and environmentally handling. If the estimated $80 \%$ (Pandey et al., 2000) of the 3.5 million mg of bagasse produced each year in Louisiana is used for energy conversion at the sugarcane mills, the SBA produced in Louisiana each year would range from 42,000 to $84,000 \mathrm{mt}$, and an estimated 2.25 to 4.5 million mt of sugarcane bagasse ash globally.

\subsection{Sugarcane Bagasse Ash Content and Uses}

SBA composition will vary depending on the source of the sugarcane, the harvesting and processing methods, and the cogeneration efficiencies (Payá et al., 2002). The primary components and percentages of SBA are $\mathrm{SiO}_{2}$ (60\%-81\%), $\mathrm{Al}_{2} \mathrm{O}_{3}$ (8\%-21\%), $\mathrm{Fe}_{2} \mathrm{O}_{3}$ (5\%-6\%), $\mathrm{CaO}$ (3.1-3.4\%), $\mathrm{K}_{2} \mathrm{O}$ (1.4-1.5\%), $\mathrm{MgO}(0.1-1.9 \%)$, and $\mathrm{Na}_{2} \mathrm{O}$ (0.2-1.1\%) (Payá et al., 2002; Zandersons et al., 1999). Sugarcane mill owners, operators, and associated researchers have investigated and employed various uses for SBA (Sales \& Lima, 2010). Due to the high $\mathrm{SiO}_{2}$ content $(60-81 \%)$ and the other components, SBA is a potential replacement for silca in concrete and mortars (Alavéz-Ramírez et al., 2012; Amin, 2011; Cordeiro et al., 2008, 2009; Paula et al., 2010; Sales \& Lima, 2010), ceramics (Souza et al., 2011), and as a stabilizing component in compacted clay blocks and bricks (Alavéz-Ramírez et al., 2012; Faria et al., 2012). One of the most common practices is the field application of SBA alone or in combination with the sugarcane mill's filter mud (Barry et al., 1998; Prasad, 1974; Sales \& Lima, 2010). Webber et al. (2016) determined that adding 25 and 75\% SBA to a certified organic growth media produced suitable potting media for cantaloupe and squash seedling production, respectively. The purpose of this research was to investigate the use of SBA as an amendment to soilless planting media for the production of additional vegetable seedlings.

\section{Material and Methods}

\subsection{Sugarcane Bagasse Ash}

Sugarcane bagasse ash was obtained from the Raceland Raw Sugar Corporation, sugarcane mill, Raceland, LA. The Raceland mill is one of 11 sugarcane mills that together processed approximately 153,783 ha and 11,576,403 $\mathrm{mt}$ of Louisiana sugarcane in 2014 (American Sugar Cane League, 2015). The SBA was combined by volume with a commercial growing media (Sunshine, Natural \& Organic Professional Growing Mix, Sun Gro Horticulture Canada Ltd, 52130 RR 65, P.O. Box 189, Seba Beach, AB TOE 2BO Canada) into 5 combinations ( $0 \%: 100 \%$, 25\%:75\%, 50\%:50\%, 75\%:25\%, and 100\%:0\%, SBA and growing media, respectively) which served as experimental treatments. Each of the soilless media treatments were thoroughly mixed prior to placing the mixtures in Speedling (Speedling In., 4447 Old HWY 41, Ruskin, FL 33570, 800-881-4769) trays (128 cells, 67.6 $\mathrm{cm} \times 34.6 \mathrm{~cm}$ trays, cells: $3.1 \mathrm{~cm}$ square $\times 6.35 \mathrm{~cm}$ deep). The mixtures were moistened to facilitate the complete and consistent filling of each of the Speedling trays. The Speedling trays were then planted with either beans (Phaseolus vulgaris L.) var. 'Bowie' (Harris Seed Co., 355 Paul Road Rochester, NY 14624 (800) 544-7938) or Chinese kale (Brassica alboglabra) var. 'South Sea' (Evergreen Y.H. Enterprises, P.O. Box 17538, Anaheim, CA 92817, USA). The bean and kale experiments were repeated twice in spring of 2016 and included 1 seed type (bean or kale) $\times 5$ soilless media mixtures $(0: 100,25: 75,50: 50,75: 25$, and 100:0) $\times 4$ replications .

\subsubsection{Physical Analysis}

Each of the 5 soilless media mixtures were analyzed for bulk density $\left(\mathrm{g} / \mathrm{cm}^{3}\right)$, porosity $(\%)$, water saturation percentage, and water at field capacity (5). Each physical test on the 5 soil media mixtures were repeated 4 times. The measuring chamber was a cylinder with a $40 \mathrm{~mm}$ inner diameter and an interior height of $64.5 \mathrm{~mm}$ with a measured volume of $81 \mathrm{~cm}^{3}$.

\subsubsection{Chemical Analysis}

Four representative samples for each media combination were collected and chemically analyzed (Brookside Laboratories, Inc., 200 White Mountain Drive, New Bremen, Ohio, 45869, www.blinc.com). The chemical data 
were subjected to ANOVA procedure and mean separation using LSD with $\mathrm{P}=0.05$ (SAS Inc., SAS, Ver. 9.0, Cary, NC).

\subsubsection{Plant Growth and Analysis}

Five seedlings from the center of each tray were harvested 20 days after planting for the bean seedlings and 33 days after planting for the kale. Each seedling was divided into above and below ground plant portions. The above ground portion was measured for plant length by measuring the distance from the media surface to the apical meristem. The upper portion of the plant was further divided into leaves and stalks. The planting media was removed from lower portion of the plants (roots) for measuring. The fresh weight of the leaves, stalks, and the roots were then determined. The plant portions were then oven dried for 2 days at $60{ }^{\circ} \mathrm{C}$ and then reweighed to determine dry weights. Plant establishment was determined at harvest by calculating the percentage of Speedling ${ }^{\circledR}$ planting cells containing viable seedlings. All data were subjected to ANOVA and mean separation using LSD with $\mathrm{P}=0.05$ (SAS Inc., SAS, Ver. 9.0, Cary, NC).

\section{Results and Discussion}

\subsection{Statistical Analysis}

When the statistical analysis determined that there were significant interactions between experiments within plant species and plant growth media $(0 \%, 25 \%, 50 \%, 75 \%$ and $100 \%$ SBA), the results will be discussed by experiments rather than averaged across experiments. Otherwise, when there is not an experiment by growing media interaction, the results will be discussed across experiments.

\subsection{Physical Analysis: Bulk Density and Porosity}

The bulk densities of the media mixtures consistently increased from 0.118 to $0.712 \mathrm{~g} / \mathrm{cm}^{3}$ as the SBA percentage increased from $0 \%$ to $100 \%$ (Table 1). And, as the media mixtures increased in SBA percentage and bulk density, the porosity, water saturation percentage, and water at field capacity decreased (Table 1). As the growing media's porosity, water saturation and field capacity decreased with higher SBA percentages, the growing media's ability to provide available water to the growing seedlings also decreased (Table 1). Decreased water availability might necessitate increasing irrigation frequency compared to the standard greenhouse media $(0 \% \mathrm{SBA})$. The increase bulk density and decrease in the other media parameters may by increase the potential plant stress in a greenhouse environment.

Table 1. Impact of sugarcane bagasse ash (SBA) percentage of growth medium on growing media bulk density $\left(\mathrm{g} / \mathrm{cm}^{3}\right)$, percent total pore space, percent water saturation, and percent water at field capacity

\begin{tabular}{|c|c|c|c|c|}
\hline $\mathrm{SBA}^{\mathrm{Z}}$ & Bulk Density & Pore Space & Water Saturation & Water at Field Capacity \\
\hline$\%$ & ------- g/ $\mathrm{cm}^{3}$------- & --------- \% --------- & -------- $\%$-------- & ------------- \% ------------ \\
\hline 0 & $0.118 \mathrm{e}^{\mathrm{y}}$ & $71.18 \mathrm{a}$ & $85.82 \mathrm{a}$ & $83.53 \mathrm{a}$ \\
\hline 25 & $0.374 \mathrm{~d}$ & $64.56 \mathrm{~b}$ & $63.27 \mathrm{~b}$ & $61.94 \mathrm{~b}$ \\
\hline 50 & $0.528 \mathrm{c}$ & $59.62 \mathrm{c}$ & $50.02 \mathrm{c}$ & $52.54 \mathrm{c}$ \\
\hline 75 & $0.615 b$ & $59.98 \mathrm{c}$ & $49.38 \mathrm{~d}$ & $48.18 \mathrm{~d}$ \\
\hline 100 & $0.712 \mathrm{a}$ & $63.79 \mathrm{~b}$ & $47.23 \mathrm{e}$ & $45.40 \mathrm{e}$ \\
\hline
\end{tabular}

Note. ${ }^{\mathrm{z} P e r c e n t a g e ~ o f ~ s u g a r c a n e ~ b a g a s s e ~ a s h ~(S B A) ~ i n ~ t h e ~ g r o w t h ~ m e d i u m ~ b a s e d ~ o n ~ v o l u m e ; ~}{ }^{\mathrm{y}}$ Means in a column followed by the same lower case letter are not significantly different at $\mathrm{P} \leq 0.05$, ANOVA.

\subsection{Chemical Analysis}

Increasing the SBA percentage significantly influenced total exchange capacity, $\mathrm{pH}$, organic matter, estimated nitrogen release, soluble sulfur (S), and phosphorus (P) (Table 2). The total exchanged capacity was decreased by $53 \%$ (14.5 ME/100 g, $0 \%$ SBA compared to $6.8 \mathrm{ME} / 100 \mathrm{~g}, 100 \% \mathrm{SBA})$, while the $\mathrm{pH}$ increased from 6.4 to 7.7 (Table 2). Decreasing the total exchange capacity and increasing the $\mathrm{pH}$ could decrease the available of nutrients to the plant seedlings. There was a twelve fold decrease in the percentage organic matter, $67.7 \%$ to $5.6 \%, 0 \%$ SBA and $100 \%$ SBA, respectively (Table 2 ). This decrease in organic matter was the primary adverse influence affecting the physical characteristics of the SBA media combinations (Table 1). The changes in estimated $\mathrm{N}$ release were less dramatic with only a $21 \%$ decrease from $145.6 \mathrm{~kg} / \mathrm{ha}$ to $115.4 \mathrm{~kg} / \mathrm{ha}, 0 \% \mathrm{SBA}$ and $100 \%$ SBA, respectively (Table 2). Fertilization during production should compensate for the decrease in N 
availability. Sulfur (S) had an 8 fold decrease as SBA percentage increased, compared to phosphorus $\left(\mathrm{P}^{\text {as }} \mathrm{P}_{2} \mathrm{O}_{5}\right.$ and $\mathrm{P}$, Mehlich III; $\mathrm{P}$ as $\mathrm{P}_{2} \mathrm{O}_{5}$ and $\mathrm{P}$, Bray II) which increased (Table 2).

Table 2. The impact of adding sugarcane bagasse ash (SBA) to a soilless greenhouse media on total exchange capacity $(\mathrm{ME} / 100 \mathrm{~g}), \mathrm{pH}$, organic matter $(\%)$, estimated nitrogen release $(\mathrm{kg} / \mathrm{ha})$, soluble sulfur (ppm), phosphorus as $\mathrm{P}_{2} \mathrm{O}_{5}(\mathrm{~kg} / \mathrm{ha})$, and phosphorus (ppm)

\begin{tabular}{|c|c|c|c|c|c|c|c|c|c|}
\hline $\mathrm{SBA}^{\mathrm{z}}$ & $\begin{array}{l}\text { Total } \\
\text { Exchange } \\
\text { Capacity }\end{array}$ & $\begin{array}{l}\mathrm{pH} \\
\left(\mathrm{H}_{2} \mathrm{O} 1: 1\right)\end{array}$ & $\begin{array}{l}\text { Organic } \\
\text { Matter } \\
\text { (humus) }\end{array}$ & $\begin{array}{l}\text { Estimated N } \\
\text { Release }\end{array}$ & Soluble S & $\mathrm{P}$ as $\mathrm{P}_{2} \mathrm{O}_{5}{ }^{\mathrm{y}}$ & $\mathrm{P}^{\mathrm{y}}$ & $\mathrm{P}$ as $\mathrm{P}_{2} \mathrm{O}_{5}{ }^{\mathrm{X}}$ & $\mathrm{P}^{\mathrm{x}}$ \\
\hline --- \% --- & $\mathrm{ME} / 100 \mathrm{~g}$ & & --- \% --- & --- kg/ha --- & -- ppm -- & -- kg/ha -- & -- ppm-- & -- kg/ha -- & -- ppm -- \\
\hline 0 & $14.5 \mathrm{a}^{\mathrm{w}}$ & $6.4 \mathrm{e}$ & $67.7 \mathrm{a}$ & $145.6 \mathrm{a}$ & $181.5 \mathrm{a}$ & $105.3 \mathrm{e}$ & $20.5 \mathrm{e}$ & $174.5 \mathrm{e}$ & $34.0 \mathrm{e}$ \\
\hline 25 & $12.8 \mathrm{a}$ & $6.7 \mathrm{~d}$ & $23.4 \mathrm{~b}$ & $145.6 \mathrm{a}$ & $138.8 \mathrm{~b}$ & $682.4 \mathrm{~d}$ & $133.0 \mathrm{~d}$ & $893.8 \mathrm{~d}$ & $174.3 \mathrm{~d}$ \\
\hline 50 & $9.7 \mathrm{~b}$ & $7.0 \mathrm{c}$ & $12.9 \mathrm{c}$ & $141.5 \mathrm{~b}$ & $82.5 \mathrm{c}$ & $899.1 \mathrm{c}$ & $175.3 \mathrm{c}$ & $1052.3 \mathrm{c}$ & $229.8 \mathrm{c}$ \\
\hline 75 & $8.5 \mathrm{bc}$ & $7.3 \mathrm{~b}$ & $9.3 \mathrm{~d}$ & $136.1 \mathrm{c}$ & $57.5 \mathrm{c}$ & $1106.9 \mathrm{~b}$ & $215.8 \mathrm{~b}$ & $1138.3 \mathrm{~b}$ & $248.5 b$ \\
\hline 100 & $6.8 \mathrm{c}$ & $7.7 \mathrm{a}$ & $5.6 \mathrm{e}$ & $115.4 \mathrm{~d}$ & $22.0 \mathrm{~d}$ & $1322.2 \mathrm{a}$ & $257.8 \mathrm{a}$ & $1178.6 \mathrm{a}$ & $262.0 \mathrm{a}$ \\
\hline
\end{tabular}

Note. ${ }^{\mathrm{z}}$ Percentage of sugarcane bagasse ash (SBA) in the growth medium based on volume; ${ }^{\mathrm{y}}$ Mehlich III; ${ }^{\mathrm{x}} \mathrm{Bray}$ II; " Means in a column followed by the same lower case letter are not significantly different at $\mathrm{P} \leq 0.05$, ANOVA.

Calcium ( $\mathrm{Ca}$ ) and magnesium $(\mathrm{Mg})$ exchange cations decreased, potassium $(\mathrm{K})$ cations increased, and sodium $(\mathrm{Na})$ cations remained constant as the SBA increased from $0 \%$ to $100 \%$ (Table 3 ). Although these results are consistent with what might be expected, they should be considered when deciding how to provide the required nutrients for various seedling or bedding plants.

Table 3. Impact of sugarcane ash percentage (SBA \%) on the exchangeable cations (calcium, magnesium, potassium, and sodium) for the five sugarcane bagasse ash and greenhouse media growing mixtures

\begin{tabular}{|c|c|c|c|c|c|c|c|c|}
\hline $\mathrm{SBA}^{\mathrm{z}}$ & $\mathrm{Ca}^{\mathrm{y}}$ & $\mathrm{Ca}^{\mathrm{y}}$ & $\mathrm{Mg}^{\mathrm{y}}$ & $\mathrm{Mg}^{\mathrm{y}}$ & $\mathrm{K}^{\mathrm{y}}$ & $\mathrm{K}^{\mathrm{y}}$ & $\mathrm{Na}^{\mathrm{y}}$ & $\mathrm{Na}^{\mathrm{y}}$ \\
\hline ---- \% ---- & ---- kg/a ---- & --- ppm --- & -- kg/ha -- & --- ppm --- & -- kg/ha -- & -- ppm -- & -- kg/ha -- & -- ppm -- \\
\hline 0 & $3816.4 \mathrm{a}^{\mathrm{w}}$ & $1703.8 \mathrm{a}$ & $952.6 \mathrm{a}$ & $425.3 \mathrm{a}$ & $154.6 \mathrm{e}$ & $69.0 \mathrm{e}$ & $122.6 \mathrm{a}$ & $54.8 \mathrm{a}$ \\
\hline 25 & $3270.4 \mathrm{~b}$ & $1460.0 \mathrm{~b}$ & $864.6 \mathrm{a}$ & $386.0 \mathrm{a}$ & $740.9 \mathrm{~d}$ & $330.8 \mathrm{~d}$ & $127.1 \mathrm{a}$ & $56.8 \mathrm{a}$ \\
\hline 50 & $2334.6 \mathrm{c}$ & $1042.3 \mathrm{c}$ & $724.6 \mathrm{~b}$ & $323.5 \mathrm{~b}$ & $950.9 \mathrm{c}$ & $424.5 \mathrm{c}$ & $124.9 \mathrm{a}$ & $55.8 \mathrm{a}$ \\
\hline 75 & $1854.2 \mathrm{c}$ & $827.8 \mathrm{c}$ & $694.0 \mathrm{bc}$ & $301.8 \mathrm{bc}$ & $1131.2 \mathrm{~b}$ & $505.0 \mathrm{~b}$ & $125.4 \mathrm{a}$ & $56.0 \mathrm{a}$ \\
\hline 100 & $1182.2 \mathrm{~d}$ & $527.8 \mathrm{~d}$ & $591.9 \mathrm{c}$ & $264.3 \mathrm{c}$ & $1321.6 \mathrm{a}$ & $590.0 \mathrm{a}$ & $114.8 \mathrm{a}$ & $51.3 \mathrm{a}$ \\
\hline
\end{tabular}

Note. ${ }^{\mathrm{z}}$ Percentage of sugarcane bagasse ash (SBA) in the growth medium based on volume; ${ }^{\mathrm{y}}$ Mehlich III; ${ }^{\mathrm{w}}$ Means in a column followed by the same lower case letter are not significantly different at $\mathrm{P} \leq 0.05, \mathrm{ANOVA}$.

Although the base saturation percentages of calcium $(\mathrm{Ca})$, magnesium $(\mathrm{Mg})$, potassium $(\mathrm{K})$, other bases, and hydrogen $(\mathrm{H})$ were significantly different among most SBA growing media, the range between the highest and lowest values were not that extreme, except for the percentage of $\mathrm{K}$, which would be expected, and the absence of $\% \mathrm{H}$ in the $50 \%$ to $100 \%$ SBA range (Table 4 ). Although the impact of these differences may not be readily seen in a short term seedling production (3-4 weeks), the impact may be more obvious when seedlings are grown for longer periods of time (4-8 weeks). 
Table 4. Impact of sugarcane ash percentage (SBA \%) as an amendment on the base saturation percentages for the five sugarcane greenhouse growing mixtures.

\begin{tabular}{|c|c|c|c|c|c|c|}
\hline $\mathrm{SBA}^{\mathrm{z}}$ & $\mathrm{Ca}$ & $\mathrm{Mg}$ & K & $\mathrm{Na}$ & Other Bases & $\mathrm{H}$ \\
\hline ----- \% ------ & ----- \% ----- & ----- \% ------ & ------ \% ------ & ------ \% ------ & ------ \% ------ & ----- \% ----- \\
\hline 0 & $58.7 \mathrm{a}^{\mathrm{y}}$ & $24.44 \mathrm{~d}$ & $1.22 \mathrm{e}$ & $1.64 \mathrm{e}$ & $5.00 \mathrm{a}$ & $9.0 \mathrm{a}$ \\
\hline 25 & $57.1 \mathrm{a}$ & $25.15 \mathrm{~d}$ & $6.63 \mathrm{~d}$ & $1.93 \mathrm{~d}$ & $4.70 \mathrm{~b}$ & $4.5 \mathrm{~b}$ \\
\hline 50 & $53.3 \mathrm{~b}$ & $27.98 \mathrm{c}$ & $11.36 \mathrm{c}$ & $2.53 \mathrm{c}$ & $4.43 \mathrm{c}$ & $0.0 \mathrm{c}$ \\
\hline 75 & $48.4 \mathrm{c}$ & $29.44 b$ & $15.17 \mathrm{~b}$ & $2.85 \mathrm{~b}$ & $4.13 \mathrm{~d}$ & $0.0 \mathrm{c}$ \\
\hline 100 & $38.5 \mathrm{~d}$ & $32.28 \mathrm{a}$ & $22.21 \mathrm{a}$ & $3.28 \mathrm{a}$ & $3.70 \mathrm{e}$ & $0.0 \mathrm{c}$ \\
\hline
\end{tabular}

Note. ${ }^{\mathrm{z}}$ Percentage of sugarcane bagasse ash (SBA) in the growth medium based on volume; ${ }^{\mathrm{y}}$ Means in a column followed by the same lower case letter are not significantly different at $\mathrm{P} \leq 0.05$, ANOVA.

All of the extractable essential minor elements concentrations (ppm) of boron (B), iron (Fe), manganese (Mn), copper $(\mathrm{Cu})$, zinc $(\mathrm{Zn})$ and aluminum $(\mathrm{AL})$ increased as the \% SBA increased (Table 5). The addition of these extractable essential minor elements through the addition of the SBA has the potential to increase the nutrient status of the growing media. These results may explain earlier research by Webber et al. (2016) where $25 \%$ and $75 \%$ SBA increased cantaloupe and squash seedling growth, respectively.

Table 5. Impact of sugarcane ash percentage (SBA \%) on extractable essential minor elements (ppm) for the five sugarcane bagasse ash (SBA) growing media

\begin{tabular}{lllllll}
\hline SBA $^{\mathrm{z}}$ & $\mathrm{B}$ & $\mathrm{Fe}$ & $\mathrm{Mn}$ & $\mathrm{Cu}$ & $\mathrm{Zn}$ & $\mathrm{Al}$ \\
\hline------ \% ------- & $----\mathrm{ppm}----$ & $----\mathrm{ppm}----$ & $----\mathrm{ppm} \mathrm{----}$ & $----\mathrm{ppm}$--- & $----\mathrm{ppm} \mathrm{----}$ & $----\mathrm{ppm} \mathrm{----}$ \\
0 & $0.20 \mathrm{c}^{\mathrm{y}}$ & $48.8 \mathrm{e}$ & $2.50 \mathrm{e}$ & $0.71 \mathrm{c}$ & $1.20 \mathrm{~d}$ & $46.50 \mathrm{e}$ \\
25 & $0.46 \mathrm{~b}$ & $163.8 \mathrm{~d}$ & $12.75 \mathrm{~d}$ & $1.02 \mathrm{~b}$ & $3.05 \mathrm{c}$ & $293.75 \mathrm{~d}$ \\
50 & $0.59 \mathrm{a}$ & $198.5 \mathrm{c}$ & $17.25 \mathrm{c}$ & $1.33 \mathrm{a}$ & $3.87 \mathrm{~b}$ & $364.50 \mathrm{c}$ \\
75 & $0.64 \mathrm{a}$ & $227.0 \mathrm{~b}$ & $20.75 \mathrm{~b}$ & $1.48 \mathrm{a}$ & $4.60 \mathrm{a}$ & $421.25 \mathrm{~b}$ \\
100 & $0.65 \mathrm{a}$ & $253.3 \mathrm{a}$ & $24.00 \mathrm{a}$ & $1.44 \mathrm{a}$ & $4.83 \mathrm{a}$ & $474.25 \mathrm{a}$ \\
\hline
\end{tabular}

Note. ${ }^{\mathrm{z}}$ Percentage of sugarcane bagasse ash (SBA) in the growth medium based on volume; ${ }^{\mathrm{y}}$ Means in a column followed by the same lower case letter are not significantly different at $\mathrm{P} \leq 0.05$, ANOVA.

\subsection{Seedling Analysis}

\subsubsection{Bean}

(1) Bean Stalk Lengths and Impact of Population

Significant interactions were detected between the planting media and experiments for bean stalk length and plant establishment; therefore, this data will be discussed by experiment (Table 6). In experiments 1 and 2 there were no consistent correlation between SBA content and bean seedling stalk lengths (Table 6). Bean plant establishment was the greatest for the $0 \%$ and $25 \%$ SBA, along with the $100 \%$ SBA in experiment 1 and $25 \%$ and 50\% SBA for experiment 2 (Table 6). 
Table 6. Impact of sugarcane bagasse ash (SBA) percentage of growth medium on bean seedling stalk length (mm) and plant population (\%) for two experiments, four replications per experiment, and five harvested seedlings per replication

\begin{tabular}{|c|c|c|c|c|}
\hline \multirow{2}{*}{$\mathrm{SBA}^{\mathrm{z}}$} & \multicolumn{2}{|c|}{ Stalk Length } & \multicolumn{2}{|c|}{ Plant Establishment } \\
\hline & Exp. \#1 & Exp. \#2 & Exp. \#1 & Exp. \#2 \\
\hline --------- \% --------- & --------- mm -------- & --------- mm -------- & -------- \% ------- & -------- \% -------- \\
\hline 0 & $89.3 \mathrm{ab}^{\mathrm{y}}$ & $133.1 \mathrm{ab}$ & $90.6 \mathrm{a}$ & $55.1 \mathrm{bc}$ \\
\hline 25 & $96.5 \mathrm{ab}$ & $141.0 \mathrm{a}$ & $88.3 \mathrm{a}$ & $76.2 \mathrm{a}$ \\
\hline 50 & $78.5 \mathrm{~b}$ & $123.6 \mathrm{ab}$ & $58.6 \mathrm{c}$ & $68.1 \mathrm{ab}$ \\
\hline 75 & $95.5 \mathrm{ab}$ & $107.0 \mathrm{bc}$ & $63.7 \mathrm{bc}$ & $58.6 \mathrm{~b}$ \\
\hline 100 & $107.0 \mathrm{a}$ & $90.4 \mathrm{c}$ & $76.6 \mathrm{ab}$ & $39.8 \mathrm{c}$ \\
\hline
\end{tabular}

Note. ${ }^{\mathrm{Z}}$ Percentage of sugarcane bagasse ash (SBA) in the growth medium based on volume; ${ }^{\mathrm{y}}$ Means in a column followed by the same lower case letter are not significantly different at $\mathrm{P} \leq 0.05$, ANOVA.

\section{(2) Bean Seedling Fresh Plant Weights}

No significant interactions were detected between the experiments and the growth media for the seedling fresh weights of the stalks, leaves, plant tops, and total plant weights, although there was an interaction between experiments and fresh root weights (Table 7). Therefore, except for the fresh root weights, the data will be discussed across both experiments. The $25 \%$ SBA produced the greatest bean fresh weights for the stalks, leaves, tops, and whole plants, while the fresh root weights peeked at $0 \% \mathrm{SBA}$ in experiment $1(4.67 \mathrm{~g})$ and at 25\% SBA in experiment $2(4.59 \mathrm{~g})$. These results were similar to those reported by Webber et al. (2016) for 25\% SBA planting media for cantaloupe seedling production.

Table 7. Impact of sugarcane bagasse ash percentage (SBA \%) of growth medium on bean seedling stalk, leaves, tops, and total fresh weights (g) averaged across two experiments, four replications per experiment, and five seedlings per replication

\begin{tabular}{|c|c|c|c|c|c|c|c|c|c|c|}
\hline \multirow{2}{*}{$\mathrm{SBA}^{\mathrm{z}}$} & \multicolumn{10}{|c|}{ Bean Seedling Fresh Weights } \\
\hline & Stalk & \multicolumn{2}{|c|}{ Leaves } & \multicolumn{2}{|c|}{ Tops } & \multicolumn{2}{|c|}{ Total } & Exp. \#1 Roots & \multicolumn{2}{|c|}{ Exp. \#2 Roots } \\
\hline$\%$ & ------ g ------ & ------ & ------ & $------\xi$ & ----- & ------ g & ------ & -------- g ------- & ------ & g ------ \\
\hline 0 & $3.51 \quad a b^{y}$ & 6.50 & $\mathrm{ab}$ & 10.01 & $\mathrm{ab}$ & 13.68 & $\mathrm{bc}$ & $4.67 \quad \mathrm{a}$ & 2.67 & $\mathrm{c}$ \\
\hline 25 & $3.95 \quad \mathrm{a}$ & 7.20 & a & 11.15 & $\mathrm{a}$ & 16.63 & $\mathrm{a}$ & 4.36 & 4.59 & a \\
\hline 50 & 3.38 & 5.96 & $\mathrm{~b}$ & 9.34 & $\mathrm{~b}$ & 12.84 & $\mathrm{c}$ & 3.37 & 3.64 & $\mathrm{~b}$ \\
\hline 75 & 3.83 & 6.59 & $a b$ & 10.42 & $a b$ & 14.56 & $a b$ & 3.79 & 4.49 & $\mathrm{a}$ \\
\hline 100 & $3.42 \mathrm{ab}$ & 6.10 & $\mathrm{~b}$ & 9.52 & $\mathrm{~b}$ & 12.59 & $\mathrm{c}$ & 2.67 & 3.48 & $\mathrm{~b}$ \\
\hline
\end{tabular}

Note. ${ }^{\mathrm{Z}}$ Percentage of sugarcane bagasse ash (SBA) in the growth medium based on volume; ${ }^{\mathrm{y}}$ Means in a column followed by the same lower case letter are not significantly different at $\mathrm{P} \leq 0.05$, ANOVA.

\section{(3) Bean Seedling Dry Plant Weights}

As a result of significant interactions between the planting media and experiments for the dry weights of the bean leaves, plant tops, and total plants, these results will be discussed by experiments (Table 8). Due to the lack of experiment by media interaction, the bean dry stalk and root weights will be discussed across experiments (Table 8). There were small but significant differences for bean dry weights of the leaves, tops, and total seedling weights, but the results were not consistent between experiments or plant materials measured (Table 8). In many cases (i.e. leaves dry weights experiments 1 and 2, top dry weights experiment 1 , total plant dry weights experiments 1 and 2), the $25 \%$ SBA produced the greatest plant weigh, although not significantly different from all other SBA media combinations (Table 8). The dry weights of the stalks and roots combined across experiments followed a similar pattern as the other dry weights (leaves, tops, and total dry weights) which had the experiment by SBA \% interactions (Table 8 ). 
Table 8. Impact of sugarcane bagasse ash percentage (SBA \%) of growth medium on bean seedling oven dried weights (stalk, leaves, tops, roots and total) two experiments, four replications per experiment, and five seedlings per replication

\begin{tabular}{|c|c|c|c|c|c|c|c|c|}
\hline \multirow[b]{2}{*}{$\mathrm{SBA}^{\mathrm{z}}$} & \multicolumn{8}{|c|}{ Bean Seedling Dry Weights } \\
\hline & Stalk & $\begin{array}{l}\text { Exp. \#1 } \\
\text { Leaves }\end{array}$ & $\begin{array}{l}\text { Exp. \#2 } \\
\text { Leaves }\end{array}$ & $\begin{array}{l}\text { Exp. \#1 } \\
\text { Tops }\end{array}$ & $\begin{array}{l}\text { Exp. \#2 } \\
\text { Tops }\end{array}$ & Roots & $\begin{array}{l}\text { Exp. \#1 } \\
\text { Total }\end{array}$ & $\begin{array}{l}\text { Exp. \#2 } \\
\text { Total }\end{array}$ \\
\hline --- \% --- & ---- g ---- & ---- g ---- & ---- g ---- & ---- g ---- & ---- g ---- & ---- g ---- & ---- g ---- & ---- g ---- \\
\hline 0 & $0.58 \mathrm{~b}^{\mathrm{y}}$ & $0.75 \mathrm{~b}$ & $1.02 \mathrm{a}$ & $1.24 \mathrm{c}$ & $1.70 \mathrm{a}$ & $0.34 \mathrm{a}$ & $1.60 \mathrm{c}$ & $2.00 \mathrm{ab}$ \\
\hline 25 & $0.68 \mathrm{a}$ & $0.98 \mathrm{a}$ & $1.05 \mathrm{a}$ & $1.57 \mathrm{a}$ & $1.18 \mathrm{a}$ & $0.37 \mathrm{a}$ & $1.94 \mathrm{a}$ & $2.18 \mathrm{a}$ \\
\hline 50 & $0.56 \mathrm{bc}$ & $0.87 \mathrm{ab}$ & $0.93 \mathrm{a}$ & $1.36 \mathrm{bc}$ & $1.57 \mathrm{a}$ & $0.33 \mathrm{a}$ & $1.67 \mathrm{bc}$ & $1.90 \mathrm{ab}$ \\
\hline 75 & $0.60 \mathrm{ab}$ & $0.97 \mathrm{a}$ & $0.87 \mathrm{a}$ & $1.53 \mathrm{ab}$ & $1.51 \mathrm{a}$ & $0.36 \mathrm{a}$ & $1.88 \mathrm{ab}$ & $1.87 \mathrm{~b}$ \\
\hline 100 & $0.49 \mathrm{c}$ & $0.86 \mathrm{ab}$ & $0.67 \mathrm{~b}$ & $1.41 \mathrm{abc}$ & $1.12 \mathrm{~b}$ & $0.33 \mathrm{a}$ & $1.47 \mathrm{c}$ & $1.47 \mathrm{c}$ \\
\hline
\end{tabular}

Note. ${ }^{\mathrm{z}}$ Percentage of sugarcane bagasse ash (SBA) in the growth medium based on volume; ${ }^{\mathrm{y}}$ Means in a column followed by the same lower case letter are not significantly different at $\mathrm{P} \leq 0.05$, ANOVA.

\section{(4) Bean Seedling Summary}

There were no consistent correlation between SBA content and bean seedling stalk lengths. Bean plant establishment was the greatest for the $0 \%$ and $25 \%$ SBA, along with the $100 \%$ SBA in experiment 1 and $25 \%$ and $50 \%$ SBA for experiment 2 . The $25 \%$ SBA produced the greatest bean fresh weights for the stalks, leaves, tops, and whole plants, while the fresh root weights peeked at $0 \% \mathrm{SBA}$ in experiment 1 and at $25 \% \mathrm{SBA}$ in experiment 2. There were small but significant differences for bean dry weights of the leaves, tops, and total seedling weights, but the results were not consistent between experiments or plant materials measured. In many cases (i.e. leaves dry weights experiments 1 and 2, top dry weights experiment 1, total plant dry weights experiments 1 and 2), the $25 \%$ SBA produced the greatest plant weights, although not significantly different from all other SBA media combinations. The dry weights of the stalks and roots combined across experiments followed a similar pattern as the other dry weights (leaves, tops, and total dry weights) which had the experiment by $\%$ SBA interactions. These results were similar to those reported by Webber et al. (2016) for 25\% SBA planting media for cantaloupe seedling production.

\subsubsection{Chinese Kale Seedling Analysis}

Except for the Chinese kale root fresh weights and plant establishment data, there were no significant interactions detected between the experiments and SBA planting media data. As a result, the Chinese root fresh weights and percent plant established will be discuss by experiment (Table 9), while the other harvest data will be discussed across experiments (Tables 10 and 11).

(1) Chinese Kale Seedling Fresh Root Weights and Establishment

Although there were significant interactions between SBA growing media and experiments for the Chinese kale fresh root weights and plant establishment, in all cases the values peaked at either $25 \%$ or $0 \%$ SBA media (Table 9).

Table 9. Impact of sugarcane bagasse ash (SBA) percentage of growth medium on Chinese kale fresh root weights (g) and plant establishment by experiments 1 and 2, four replications per experiment, and five seedlings per replication

\begin{tabular}{|c|c|c|c|c|}
\hline \multirow{2}{*}{$\mathrm{SBA}^{\mathrm{z}}$} & \multicolumn{2}{|c|}{ Roots Fresh Weight } & \multicolumn{2}{|c|}{ Plant Establishment } \\
\hline & Exp. \#1 & Exp. \#2 & Exp. \#1 & Exp. \#2 \\
\hline ------------ \% ------------ & --------- g --------- & ---------- g ---------- & --------- g --------- & --------- g --------- \\
\hline 0 & $0.55 \mathrm{bc}^{\mathrm{y}}$ & $0.32 \mathrm{ab}$ & $71.49 \mathrm{a}$ & $96.10 \mathrm{a}$ \\
\hline 25 & $0.85 \mathrm{a}$ & $0.37 \mathrm{a}$ & $80.08 \mathrm{~b}$ & $94.92 \mathrm{a}$ \\
\hline 50 & $0.79 \mathrm{ab}$ & $0.21 \mathrm{bc}$ & $33.99 \mathrm{~b}$ & $58.60 \mathrm{~b}$ \\
\hline 75 & $0.40 \mathrm{c}$ & $0.23 \mathrm{~b}$ & $17.58 \mathrm{c}$ & $53.52 \mathrm{~b}$ \\
\hline 100 & $0.31 \mathrm{c}$ & $0.10 \mathrm{c}$ & $25.39 \mathrm{bc}$ & $13.28 \mathrm{c}$ \\
\hline
\end{tabular}

Note. ${ }^{\mathrm{Z}}$ Percentage of sugarcane bagasse ash (SBA) in the growth medium based on volume; ${ }^{\mathrm{y}}$ Means in a column followed by the same lower case letter are not significantly different at $\mathrm{P} \leq 0.05$, ANOVA. 
(2) Chinese Kale Stalk Lengths, and Fresh Weights of Stalks, Leaves, Tops, and Total Plant

The 25\% SBA growing media consistently produced the greatest Chinese kale stalk lengths and fresh plant weights (stalks, leaves, tops, and total plant) (Table 10). As the SBA content increased from $25 \%$ to $100 \%$ SBA, the plant lengths and fresh weights consistently decreased (Table 10). These results follow a similar pattern as the impact of the SBA \% on bean fresh weights (Table 7), and cantaloupe seedling data reported by Webber et al. (2016).

Table 10. Impact of sugarcane bagasse ash (SBA) percentage of growth medium on Chinese kale seedling stalk lengths $(\mathrm{mm})$ and plant fresh weights $(\mathrm{g})$ averaged across two experiments, four replications per experiment, and five seedlings per replication.

\begin{tabular}{|c|c|c|c|c|c|}
\hline \multirow{2}{*}{$\mathrm{SBA}^{\mathrm{z}}$} & \multirow{2}{*}{ Stalk Length } & \multicolumn{4}{|c|}{ Fresh Weight } \\
\hline & & Stalks & Leaves & Tops & Total \\
\hline ------- \% -------" & ------ mm ----- & -------- g -------- & 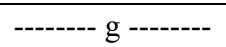 & -------- g -------- & 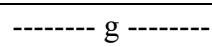 \\
\hline 0 & $19.9 \mathrm{~b}^{\mathrm{y}}$ & $0.15 \mathrm{~b}$ & $0.59 \mathrm{bc}$ & $0.74 \mathrm{~b}$ & $1.17 \mathrm{~b}$ \\
\hline 25 & $23.5 \mathrm{a}$ & $0.21 \mathrm{a}$ & $0.75 \mathrm{a}$ & $0.96 \mathrm{a}$ & $1.57 \mathrm{a}$ \\
\hline 50 & $19.8 \mathrm{~b}$ & $0.15 \mathrm{~b}$ & $0.59 \mathrm{~b}$ & $0.74 \mathrm{~b}$ & $1.24 \mathrm{~b}$ \\
\hline 75 & $16.6 \mathrm{c}$ & $0.11 \mathrm{c}$ & $0.57 b c$ & $0.68 \mathrm{bc}$ & $0.99 \mathrm{bc}$ \\
\hline 100 & $15.8 \mathrm{c}$ & $0.09 \mathrm{c}$ & $0.46 \mathrm{c}$ & $0.55 \mathrm{c}$ & $0.76 \mathrm{c}$ \\
\hline
\end{tabular}

Note. ${ }^{\mathrm{z}}$ Percentage of sugarcane bagasse ash (SBA) in the growth medium based on volume; ${ }^{\mathrm{y}}$ Means in a column followed by the same lower case letter are not significantly different at $\mathrm{P} \leq 0.05$, ANOVA.

\section{(3) Chinese Kale Seedling Dry Weights}

Chinese kale seedling dry weights (Table 11) responded to SBA\% in the same manner as the Chinese kale fresh weighs (Table 10). The stalks, leaves, tops, and total plant dry weights peaked at the $25 \%$ SBA, and significantly decreased as the percentage of SBA was added to the growing media (Table 11), while root weights were not as significantly different, but tended to decrease as the SBA percentage increased (Table 11). These results are also consistent to those reported by Webber et al. (2016) concerning cantaloupe seedling dry weights.

Table 11. Impact of sugarcane bagasse ash (SBA) percentage of growth medium on Chinese kale seedling on Plants dry weights (g) averaged across two experiments, four replications per experiment, and five seedlings per replication.

\begin{tabular}{|c|c|c|c|c|c|}
\hline \multirow{2}{*}{$\mathrm{SBA}^{\mathrm{z}}$} & \multicolumn{5}{|c|}{ Dry Weights } \\
\hline & Stalks & Leaves & Tops & Roots & Total \\
\hline ------- \% ------- & ------- g ------- & ------- g ------- & ------- g ------- & ------- g ------- & ------- g ------- \\
\hline 0 & $0.018 \mathrm{~b}$ & $0.11 \mathrm{~b}$ & $0.12 \mathrm{~b}$ & $0.074 \mathrm{a}$ & $0.20 \mathrm{ab}$ \\
\hline 25 & $0.032 \mathrm{a}$ & $0.15 \mathrm{a}$ & $0.18 \mathrm{a}$ & $0.053 \mathrm{ab}$ & $0.24 \mathrm{a}$ \\
\hline 50 & $0.018 \mathrm{~b}$ & $0.10 \mathrm{~b}$ & $0.12 \mathrm{~b}$ & $0.044 \mathrm{ab}$ & $0.17 \mathrm{bc}$ \\
\hline 75 & $0.016 \mathrm{~b}$ & $0.07 \mathrm{c}$ & $0.08 \mathrm{c}$ & $0.026 \mathrm{ab}$ & $0.11 \mathrm{~cd}$ \\
\hline 100 & $0.01 \mathrm{c}$ & $0.05 \mathrm{c}$ & $0.06 \mathrm{c}$ & $0.015 \mathrm{~b}$ & $0.08 \mathrm{~d}$ \\
\hline
\end{tabular}

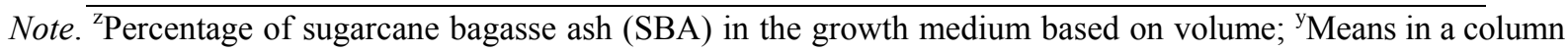
followed by the same lower case letter are not significantly different at $\mathrm{P} \leq 0.05$, ANOVA.

\section{(4) Chinese Kale Seedling Summary}

Although there are significant interactions between SBA growing media and experiments for the Chinese kale fresh root weights and plant establishment, in all cases the values peaked at either $25 \%$ or $0 \%$ SBA media. The $25 \%$ SBA growing media consistently produced the greatest Chinese kale stalk lengths, and fresh and dry plant weights (stalks, leaves, tops, and total plant). In addition, as the SBA content increased from $25 \%$ to $100 \%$ SBA, the plant lengths and weights consistently decreased. These results follow a similar pattern as the impact of the SBA $\%$ on bean fresh weights (Table 7). Webber et al. (2016) also observed a beneficial impact of adding $25 \%$ 
SBA to a soilless growing media on cantaloupe seedling growth with a corresponding decrease in growth at the higher SBA percentages.

\section{Conclusions}

The SBA mixture bulk densities consistently increased from 0.118 to $0.712 \mathrm{~g} / \mathrm{cm}^{3}$ as the SBA percentage increased from $0 \%$ to $100 \%$, while the porosity, water saturation percentage, and water at field capacity decreased. As the bulk densities increased and the water holding capacity decreased, the growing media became less conducive to plant growth and more difficult to manage, increasing the potential for plant stress in a greenhouse environment.

Increasing the SBA percentage significantly influenced total exchange capacity, $\mathrm{pH}$, organic matter, estimated nitrogen release, and all other nutrients measured, except for sodium. Although the bean and Chinese kale seedlings neither exhibited deficiency nor toxicity symptoms, the impact of the $\mathrm{pH}$ alone would need to be addressed in the future use of SBA depending on the seedlings grown. Additional nutrient requirements could be supplied at planting and through maintenance fertilizers during production.

Bean and Chinese kale plant parameters at harvest typically peaked at $25 \%$ SBA, and then decreased with increasing SBA \%. Adding $25 \%$ SBA to a commercial greenhouse media did benefit the seedling growth, providing additional nutrients for seedling growth, while reducing the cost of production my supplementing the more expensive greenhouse media by a readily available by-product of the sugarcane industry. Increasing the SBA $\%$ to $50 \%$ or greater is not recommend, but additional research should explore at what percentage of SBA above $25 \%$ and below $50 \%$ would still benefit seedling plant growth.

\section{Acknowledgements}

The authors would also like to thank the Raceland Raw Sugar Corporation, Raceland, LA for providing the sugarcane bagasse ash. The work would have been impossible without the technical support of USDA, Agricultural Research Service technicians Derek Landrum, Christopher Adams, Eric Petrie, Norris Matherne, and Frank Randell for their technical support.

\section{Trade Names or Commercial Products}

Mention of trade names or commercial products in this publication is solely for the purpose of providing specific information and does not imply recommendation or endorsement by the U.S. Department of Agriculture.

\section{EEO/Non-Discrimination Statement}

The U.S. Department of Agriculture (USDA) prohibits discrimination in all its programs and activities on the basis of race, color, national origin, age, disability, and where applicable, sex, marital status, familial status, parental status, religion, sexual orientation, genetic information, political beliefs, reprisal, or because all or part of an individual's income is derived from any public assistance program. (Not all prohibited bases apply to all programs.) Persons with disabilities who require alternative means for communication of program information (Braille, large print, audiotape, etc.) should contact USDA's TARGET Center at (202) 720-2600 (voice and TDD). To file a complaint of discrimination, write to USDA, Director, Office of Civil Rights, 1400 Independence Avenue, S.W., Washington, D.C. 20250-9410, or call (800) 795-3272 (voice) or (202) 720-6382 (TDD). USDA is an equal opportunity provider and employer.

\section{References}

Alavéz-Ramírez, R., Montes-García, P., Martínez-Reyes, J., Altamirano-Juárez, D. C., \& Gochi-Ponce, Y. (2012). The use of sugarcane bagasse ash and lime to improve the durability and mechanical properties of compacted soil blocks. Construction and Building Mater., 34, 296-305. https://doi.org/10.1016/ j.conbuildmat.2012.02.072

American Sugar Cane League. (2015). The Louisiana sugar industry (pp. 1-8). Retrieved from $\mathrm{http} / /$ www.amscl.org/Images/Interior/sugar\%20industry\%20pamphlet/sugarindustrymediakit.pdf

Amin, N. (2011). Use of bagasse ash in concrete and its impact on the strength and chloride resistivity. J. Mater. Civ. Eng., 23(5), 717-720. https://doi.org/10.1061/(ASCE)MT.1943-5533.0000227

Badger, P. C. (2002). Ethanol from cellulose: A general review. In J. Janick \& A. Whipkey (Eds.), Trends in new crops and new uses (pp. 17-21). ASHS Press, Alexandria, VA.

Barry, G. A., Price, A. M., \& Lynch, P. J. (1998). Some implications of the recycling of sugar industry by-products. Proc. Aust. Soc. Sugar Cane Technol., 20, 52-55. 
Biricik, H., Aköz, F., Berktay, I., \& Tulgar, A. N. (1999). Study of pozzolanic properties of wheat straw ash. Cement and Concrete Res., 29, 637-643. https://doi.org/10.1016/S0008-8846(98)00249-X

Cardona, C. A., Quintero, J. A., \& Paz, I. C. (2010). Production of bioethanol from sugarcane bagasse: Status and perspectives. Bioresource Techn., 101(13), 4754-4766. https://doi.org/10.1016/j.biortech.2009.10.097

Cordeiro, G. C., Filho, R. D. T., Tavares, L. M., \& Fairbairn, E. M. R. (2008). Pozzolanic activity and filler effect of sugar cane bagasse ash in Portland cement and lime mortars. Cement and Concrete Composites, 30(5), 410-418. https://doi.org/10.1016/j.cemconcomp.2008.01.001

Cordeiro, G. C., Filho, R. D. T., Tavares, L. M., \& Fairbairn, E. M. R. (2009). Ultrafine grinding of sugar cane bagasse ash for application as pozzolanic admixture in concrete. Cement and Concrete Res., 39(2), 110-115. https://doi.org/10.1016/j.cemconres.2008.11.005

Drummond, A.-R. F., \& Drummond, I. W. (1996). Pyrolysis of Sugar Cane Bagasse in a Wire-Mesh Reactor. Ind. Eng. Chem. Res., 35(4), 1263-1268. https://doi.org/10.1021/ie9503914

Faria, K. C. P., Gurgel, R. F., \& Holanda. J. N. F. (2012). Recycling of sugarcane bagasse ash waste in the production of clay bricks. J. of Environ. Management, 101, 7-12. https://doi.org/10.1016/j.jenvman. 2012.01.032

Garcia-Pèrez, M., Chaala, A., \& Roy, C. (2002). Vacuum pyrolysis of sugarcane bagasse. J. of Analytical and Applied Pyrolysis, 65(2), 111-136. https://doi.org/10.1016/S0165-2370(01)00184-X

Guo, G. L., Hsu, D. C., Chen, W. H., Chen, W. H., \& Hwang, W. S. (2009). Characterization of enzymatic saccharification for acid-pretreated lignocellulosic materials with different lignin composition. Enzyme and Microbial Techn., 45(2), 80-87. https://doi.org/10.1016/j.enzmictec.2009.05.012

Jhurree-Dussoruth, B., Kallydin, H., \& Bornes, Q. (2011). Investigation into low-cost medium for hardening of in vitro banana plantlets to promote adoption of disease-free plants. Acta Hort., 897, 489-490. https://doi.org/10.17660/ActaHortic.2011.897.69

Kilicaslan, I., Sarac, H. I., Ozdemir, E., \& Ermis, K. (1999). Sugar cane as an alternative energy source for Turkey. Energy Conversion \& Management, 40(1), 1-11. https://doi.org/10.1016/S0196-8904(98)00103-4

Martin, C., Klinke, H. B., \& Thomsen, A. B. (2007). Wet oxidation as a pretreatment method for enhancing the enzymatic convertibility of sugarcane bagasse. Enzyme and Microbial Techn., 40, 426-432. https://doi.org/ 10.1016/j.enzmictec.2006.07.015

Nigam, P. (1990). Investigation of some factors important for solid state fermentation of sugar cane bagasse for animal feed production. Enzyme and Microbial Techn., 12(1990), 808-811. https://oi.org/10.1016/ 0141-0229(90)90156-K

Pandey, A., Soccol, C. R., Nigam, P., \& Soccol, V. T. (2000). Biotechnological potential of agro-industrial residues. I: sugarcane bagasse. Bioresource Technol., 74(1), 69-80. https://doi.org/10.1016/S0960-8524 (99)00142-X

Paula, M. O. D., Tinôco, I. D. F. F., \& Saraz, J. A. O. (2010). Sugarcane bagasse ash as a partial portland cement replacement material. Dyna., 77, 47-54.

Payá, J., Monzó, J., Borrachero, M. V., Díaz-Pinzón, L., \& Ordóňez, L. M. (2002). Sugar-cane bagasse ash (SCBA): Studies on its properties for reusing in concrete production. J. Chem Technol. Biotechnol., 77, 321-325. https://doi.org/10.1002/jctb.549

Peng, F., Ren, J. L., Xu, F., Bian, J., Peng, P., \& Sun, R. C. (2009). Comparative study of hemicelluloses obtained by graded ethanol precipitation from sugarcane bagasse. J. Agric. Food Chem., 57(14), 6305-6317. https://doi.org/10.1021/jf900986b

Prasad, M. (1974). The effect of filter press mud on the availability of macro-and micronutrients. Proc. Intern. Soc. of Sugar Cane Technologists, Sudáfrica (pp. 568-575). ZA. Hayne \& Gibson.

Sales, A., \& Lima, S. A. (2010). Use of Brazilian sugarcane bagasse ash in concrete as sand replacement. Waste Management, 30(6), 1114-1122. https://doi.org/10.1016/j.wasman.2010.01.026

Souza, E., Teixeira, S. R., Santos, G. T. A., Costa, F. B., \& Longo, E. (2011). Reuse of sugarcane bagasse ash (SCBA) to produce ceramic materials. J. of Environ. Management, 92(10), 2774-2780. https://doi.org/ 10.1016/j.jenvman.2011.06.020 
Sun, Y., \& Cheng, J. (2002). Hydrolysis of lignocellulosic materials for ethanol production: A review. Bioresource Technol., 83(1), 1-11. https://doi.org/10.1016/S0960-8524(01)00212-7

Trochoulias, T., Burton, A. J., \& White, E. (1990). The use of bagasse as a potting medium for ornamentals. Scientia Horticulturae, 42(1-2), 161-167. https://doi.org/10.1016/0304-4238(90)90157-A

United Staes Department of Agriculture, Foreign Agricultural Service. (2015). Sugar: World markets and trade. Retrieved October 15, 2015, from http://apps.fas.usda.gov/psdonline/circulars/Sugar.pdf

Webber, C. L. III, White, P. M. Jr., Petrie, E. C., Shrefler, J. W., \& Taylor, M. J. (2016). Sugarcane Bagasse Ash as a Seedling Growth Media Component. J. of Agricultural Sci., 8(1), 1-7. https://doi.org/10.5539/ jas.v7n12pxx

Xin, L., Kondo, R., \& Sakai, K. (2002). Biodegradation of sugarcane bagasse with marine fungus Phlebia sp. MG-60. J. Wood Sci., 48, 159-162. https://doi.org/10.1007/BF00767294

Zandersons, J., Gravitis, J., Kokorevics, A., Zhurinsh, A., Bikovens, O., Tardenaka, A., \& Spince, B. (1999). Studies of the Brazilian sugarcane bagasse carbonisation process and products properties. Biomass and Bioenergy, 17(3), 209-219. https://doi.org/10.1016/S0961-9534(99)00042-2

\section{Copyrights}

Copyright for this article is retained by the author(s), with first publication rights granted to the journal.

This is an open-access article distributed under the terms and conditions of the Creative Commons Attribution license (http://creativecommons.org/licenses/by/4.0/). 